J. Akademika Kim. 6(4): 227-231, November 2017

ISSN 2302-6030 (p), 2477-5185 (e)

\title{
PENGARUH PEMBELAJARANSELF DIRECT LEARNING BERBASIS TEKNOLOGI INFORMASI TERHADAP HASIL BELAJAR SISWA PADA MATERI STRUKTUR ATOM DI KELAS X SMA NEGERI 9 PALU
}

\author{
Effect of Self Direct Learning Based on Information Technology towards Learning Outcomes of \\ Students in Structure of Atoms Material in ClassX SMA Negeri 9 Palu
}

\author{
*Novita Septiani Ering, Kasmudin Mustapa, dan Minarni R. Jura \\ Pendidikan Kimia/FKIP - Universitas Tadulako, Palu - Indonesia 94118 \\ Received 12 September 2017, Revised 11 October 2017, Accepted 13 November 2017
}

\begin{abstract}
The aim of this study was to investigate the effect of self direct learning based on information technology toward learning outcomes of students in structure of atoms material in class X SMA 9 Palu. The population in this study was students of class $X$ academic year 2016-2017. The sample were students $(n=26)$ in the class $X A$ as an experimental class (learning by direct self learning) and students $(n=25)$ in the class $X C$ as the control class (learning by the conventional method). The data collection was done using an instrument of test results of studying chemistry at the structure of atoms material is valid. The data testing were using t-test statistical analysis of the two parties with the prerequisite test, the normality and homogeneity test. The data analysis results obtained that an average score of the experimental class $=71.04$ and for the control class gained an average $=$ 64.80. Based on the statistical hypothesis testing of test two parties obtained that value $t_{\text {calculation }}=6,50$ and $t_{\text {table }}=$ 2,00at $\alpha=0,05$. In this case, $H_{1}$ was accepted and $H_{0}$ was rejected, because talculation was in the rejection area of $H_{0}$. This shows that there was an effect on differences in learning outcomes of students that were taught by selfdirect learning and by the conventional method in the structure of atoms material in class X SMA 9 Palu.
\end{abstract}

Keywords: Self direct learning, learning outcomes, structure of atoms, information technology

\section{Pendahuluan}

Proses pembelajaran selama ini masih didominasi oleh guru sehingga belum memberikan kesempatan bagi siswa untuk berkembang secara mandiri melalui penemuan dan proses berpikir. Cara guru mengajar yang hanya satu arah (teacher centered) menyebabkan penumpukan informasi atau konsep saja kurang bermanfaat bagi siswa. Guru selalu menuntut siswa untuk belajar, tetapi tidak mengajarkan bagaimana siswa seharusnya belajar dan menyelesaikan masalah (Setyorini, 2011).

Permasalahan yang timbul adalah pendidikan kita masih didominasi oleh pandangan bahwa pengetahuan sebagai perangkat fakta-fakta yang harus dihafal.Banyak fakta bahwa guru menguasai materi suatu subjek dengan baik tetapi tidak dapat melaksanakan kegiatan pembelajaran dengan baik.Hal itu terjadi karena kegiatan tersebut tidak didasarkan pada model pembelajaran tertentu sehingga hasil belajar yang diperoleh siswa rendah. Proses belajar mengajar di dalam kelas masih berfokus pada guru sebagai sumber utama pengetahuan, dimana ceramah menjadi pilihan utama proses belajar mengajar (Falestin, 2010). Guru dalam proses pembelajaran tidak dapat hanya

*Correspondence

Novita Septiani Ering

Program Studi Pendidikan Kimia, Fakultas Keguruan dan IImu

Pendidikan, Universitas Tadulako

e-mail: novitaering.06@gmail.com

Published by Universitas Tadulako 2017 semata-mata memberikan pengetahuan kepada siswa. Siswa harus membangun pengetahuan di dalam benaknya sendiri (Manggala, dkk., 2013).

Kemandirian belajar merupakan kesiapan dari individu yang mau dan mampu untuk belajar dengan inisiatif sendiri, dengan atau tanpa bantuan pihak lain dalam hal penentuan tujuan belajar, metoda belajar, dan evaluasi hasil belajar. Dalam kemandirian belajar, inisiatif merupakan indikator yang sangat mendasar. Dalam pengertiannya yang lebih luas, kemandirian belajar mendeskripsikan sebuah proses di mana individu mengambil inisiatif sendiri, dengan atau tanpa bantuan orang lain, untuk mendiagnosis kebutuhan belajar, memformulasikan tujuan belajar, mengidentifikasi sumber belajar, memilih dan menentukan pendekatan strategi belajar, dan melakukan evaluasi hasil belajar yang dicapai. Dalam kemandirian belajar, inisiatif merupakan indikator yang sangat mendasar. Dalam pengertiannya yang lebih luas, kemandirian belajar mendeskripsikan sebuah proses di mana individu mengambil inisiatif sendiri, dengan atau tanpa bantuan orang lain, untuk mendiagnosis kebutuhan belajar, memformulasikan tujuan belajar, mengidentifikasi sumber belajar, memilih dan menentukan pendekatan strategi belajar, dan melakukan evaluasi hasil belajar yang dicapai (Tahar, 2006).

Model pembelajaran yang dapat mengembangkan kemandirian belajar dan keterampilan berpikir kritis siswa diantaranya adalah model SDL berbasis teknologi informasi (TI). Knowles (1975) mengajukan tiga tahap pembelajaran SDL berbasis TI yaitu (1) planning, 
(2) monitoring dan (3) evaluating. Tahapan SDL berbasis TI tersebut dapat dihubungkan dengan keterampilan berpikir kritis dan kemandirian belajar siswa. Planning merupakan aktivitas awal yang dapat memunculkan indikator berpikir kritis, yaitu mempertimbangkan kredibilitas sumber dan menumbuhkan elemen kemandirian belajar yaitu motivasi, monitoring menciptakan lingkungan belajar dan mengembangkan rencana kegiatan merupakan aktivitas yang dapat memunculkan indikator berpikir kritis yaitu berinteraksi dengan orang lain dan menumbuhkan elemen kemandirian belajar self management dan evaluating berkaitan dengan elemen kemandirian belajar self monitoring. Tahapan SDL yang demikian membutuhkan bantuan media ajar yang menunjang dalam pembelajaran, khususnya pelajaran kimia.

Pembelajaran kimia di tingkat SMA memerlukan media yang representatif, khususnya untuk level sub mikro. Kimia merupakan pelajaran yang memiliki tiga level utama yaitu sub mikro, simbolik dan makro (Bowen, 1998; Rushell, dkk., 1997). Perkembangan teknologi informasi saat ini telah menarik perhatian banyak kalangan termasuk kalangan pelajar. Mulai dari berbagai jenis telepon genggam, komputer, dan internet merupakan produk dari teknologi informasi. Salah satu produk dari teknologi informasi yang sangat bermanfaat bagi dunia pendidikan adalah teknologi komputer. Teknologi komputer dalam dunia pendidikan diaplikasikan dalam bentuk multimedia yang berfungsi sebagai perangkat lunak (software), yang memberikan fasilitas kepada siswa untuk mempelajari suatu materi (Bakrowi, 2008).

Penerapan beberapa model-model pembelajaran kooperatif telahditerapkandi SMA Negeri 9 Palu dan memberikan pengaruh yang positif terhadap hasil belajar siswa. Walaupun sudah diterapkannya model-model pembelajaran kooperatif, penerapan model pembelajaran self directed learning diharapkan juga dapat dijadikan sebagai salah satu alternatif dalam mengatasi permasalahan yang timbul selama proses pembelajaran berlangsung. Selain itu, penerapan model pembelajaran kooperatif self directed learning diharapkan juga dapat meningkatkan hasil belajar pada materi struktur atom.

Tulisan ini dimaksudkan untuk mendeskripsikan pengaruh pembelajaran self directed learning berbasis teknologi informasi terhadap hasil belajar siswa pada materi struktur atom di kelas X SMA Negeri 9 Palu.

\section{Metode}

Penelitian ini dilakukan di SMA Negeri 9 Palu.Populasi dalam penelitian ini yaitu siswa kelas $\mathrm{X}$ di SMA Negeri 9 Palu yang terdaftar pada tahun ajaran 2016/2017 sebanyak 51 orang.Teknik pengambilan sampel yang digunakan yaitu purposivesampling. Sampel dari penelitian ini yaitu siswa kelas XA yang berjumlah 26 orang dan siswa kelas XC yang berjumlah 25 orang.Pemilihan siswa kelas eksperimen dan siswa kelas control berdasarkan hasil pretest yang diperoleh. Siswa yang memiliki nilai rata-rata pretest rendah dijadikan sebagai kelompok eksperimen (kelas XA), sedangkan siswa yang memiliki nilai rata-rata pretest lebih tinggi dijadikan sebagai kelompok kontrol (kelas XC).

\section{Tahapan Penelitian}

Teknik pengumpulan data pada penelitian ini diperoleh melalui proses pembelajaran dan tes evaluasi tentang struktur atom yang diberikan kepada siswa setelah akhir pembelajaran. Penelitian ini dilakukan dengan 3 tahapanya itu tahap persiapan meliputi observasi lokasi penelitian dan mewawancarai guru, menentukan populasi dan sampel, dan merancang rencana pelaksanaan pembelajaran (RPP), membuat Lembar Kerja Siswa (LKS), dan membuat soal tes yang berupa soal pilihan ganda. Tahap pelaksanaan meliputi memberikan tes awal (pre-test) pada pertemuan pertama, melakukan kegiatan belajar mengajar untuk materi struktur atom sesuai dengan rencana pelaksanaan pembelajaran (RPP) yang telah disusun, dan memberikan tes evaluasi akhir (postest). Tahap akhir yaitu mengolah dan menganalisis data serta melaporkan hasil penelitian.

\section{Instrumen penelitian}

Penelitian ini menggunakan instrumen berupa lembar kerja siswa (LKS) dan tes hasil belajar.Tes hasil berupa pilihan ganda (soal objektif) yaitu soal yang jawabannyatelah disediakan dan tugas siswa yaitu memilih satu pilihan jawaban.Tipe soal yang digunakan meliputi ranah kognitif yang meliputi pengetahuan (ingatan), pemahaman, dan penerapan (aplikasi). Tes hasil belajar ini disusun dengan maksud untuk memperoleh data hasil belajar siswa setelah proses belajar-mengajar, sehingga diketahui ada tidaknya pengaruh self directed learning dalam pembelajaran struktur atom pada siswa kelas X di SMA Negeri 9 Palu.

\section{Teknik analisis data}

Teknik analisis data yang digunakan pada penelitian ini yaitu analisis statistik deskriptif dan analisis statistik inferensial.Teknik analisis statistik deskriptif digunakan untuk menggambarkan pencapaian masing-masing variabel dengan menentukan hubungan nilai pretes dan postes pada kelas eksperimen maupun kelas kontrol dengan menggunakan uji N-gain (Liliawati, dkk., 2013).

Analisis statistik inferensial adalah teknik statistik yang digunakan untuk menganalisis data sampel dan hasilnya diberlakukan untuk populasi. Teknik ini menggunakan metode statistik parametrik untuk menguji hipotesis yang akan menentukan kita dalam menarik kesimpulan dengan uji prasyarat pengujian normalitas dan pengujian homegenitas (kesamaan dua varians). Pengujian hipotesis pada penelitian ini menggunakan uji t-dua pihak sampel independent (tidak berpasangan) (Sudjana, 2005). Uji ini 
dilakukan karena jumlah sampel pada penelitian ini tidak sama. Jika $\mathrm{n}_{1} \neq \mathrm{n}_{2}$ dan varians homogen digunakan rumus polled varians, tujuan dari uji ini adalah untuk menguji hipotesis yang selanjutnya menarik kesimpulan tentang perbedaan hasil belajar siswa menggunakan metode pembelajaran self directed learning dengan hasil belajar siswa menggunakan metode konvensional.

\section{Hasil dan Pembahasan}

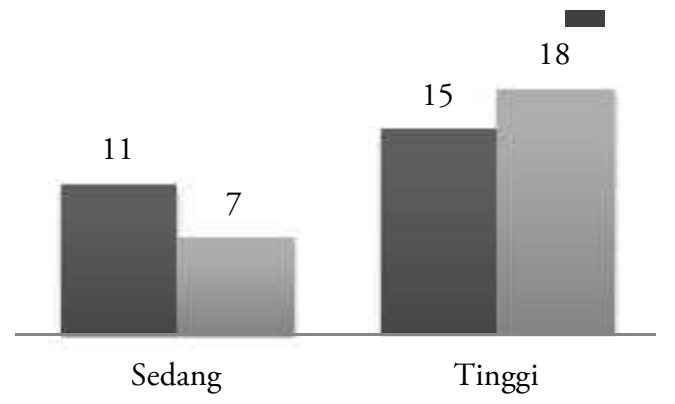

Gambar1. Nilai-Gain kelas eksperimen kelas kontrol

Data hasil pengujian analisis statistik deskriptif yang digunakan untuk menggambarkan pencapaian masing-masing variabel dengan menentukan hubungan nilai pretes dan postes pada kelas eksperimen maupun kelas kontrol dengan menggunakan uji $\mathrm{N}$-gain. Walaupun perbedaan nilai N-gain dari kedua kelas tidak terlalu berbeda secara siginifikan, pembelajaran dengan menggunakan model pembelajaran self directed learning memberikan hasil belajar yang lebih tinggi, hal ini dikarenakan model pembelajaran self directed learning merupakan model pembelajaran mandiri yang juga sangat efektif untuk diterapkan kepada siswa.

Postest yang dilakukan bertujuan untuk mengetahui sejauh mana pengaruh model pembelajaran self directed learning terhadap hasil belajar kimia siswa pada materi Struktur atom. Berdasarkan penelitian yang dilakukan, diperoleh data dari kelas eksperimen dan kelas control pada Tabel 1.

Tabel 1.Hasil belajar kimia tentang stuktur atom pada siswa kelas eksperimen dan kelas kontrol

\begin{tabular}{ccc}
\hline Uraian & Kelas Kontrol & Kelas Eksperimen \\
\hline Nilai Tertinggi & 86 & 91 \\
Nilai Terendah & 45 & 50 \\
\hline Nilai rata-rata & 64,8 & 71,04 \\
\hline
\end{tabular}

Berdasarkan hasil penelitian dan analisis data diperoleh bahwa hasil belajar kimia, siswa yang mengikuti metode pembelajaran self directed learning (kelas eksperimen) meningkat dibandingkan dengan siswa yang mengikuti metode pembelajaran konvensional (kelas kontrol). Hal ini dapat dilihat dari nilai rata-rata yang diperoleh siswa kelas eksperimen $=71,04$ dengan simpangan baku $=11,74$ dan nilai rata-rata siswa kelas kontrol $=64,80$ dengan simpangan baku $=$ 11,43. Artinya antara siswa pada kelas eksperimen dan kelas kontrol sama-sama memiliki skor yang berdistribusi normal karena simpangan baku dari skor rata-ratanya kecil. Data selengkapnya mengenai nilai rata-rata kelas eksperimen dan kelas kontrol dapat dilihat pada lampiran.

Pengujian normalitas dan homogenitas merupakan uji prasyarat untuk statistik uji-t dalam hal ini digunakan uji kesamaan dua ratarata: uji dua pihak. Berdasarkan uji normalitas data tes hasil belajar untuk kelas eksperimen diperoleh nilai $\chi^{2}$ hitung $<\chi_{\text {tabel }}^{2}(5,09<7,81)$ dan normalitas data untuk kelas kontrol diperoleh $\chi_{\text {hitung }}^{2}<\chi_{\text {tabel }}^{2}(3,11<7,81)$. Hasil tersebut menunjukan baik kelas eksperimen maupun kelas kontrol mempunyai data yang berdistribusi normal. Ini berarti bahwa data yang diperoleh mempunyai sebaran merata antara hasil belajar siswa yang rendah, sedang, dan tinggi yaitu memenuhi kurva normal.

Berdasarkan uji homogenitas data tes hasil belajar diperoleh nilai $\mathrm{F}_{\text {hitung }}<\mathrm{F}_{\text {tabel, }}$ yaitu $1,03<$ 1,96 dengan $\alpha=0,05$ maka $\mathrm{H}_{0}$ diterima. Hal ini dapat diartikan bahwa tidak terdapat perbedaan varians antara kelas kontrol dan kelas eksperimen maka data bersifat homogen. Homogennya data menunjukkan bahwa tingkat kemampuan antara kedua kelas yang telah dipilih sebagai sampel sama. Data yang diperoleh berdistribusi normal dan bersifat homogen, sehingga data dapat diuji dengan menggunakan statistik uji-t dua pihak.

Data yang diperoleh berdistribusi normal dan memiliki tingkat homogenitas yang baik pada tingkat kepercayaan 95\%, maka data tersebut dapat dilanjutkan dengan uji-t, yaitu untuk mengetahui ada atau tidak adanya perbedaan (kesamaan) dua kelompok data. Uji-t tersebut terbatas untuk mencari perbedaan dua kelompok data saja. Kelompok data yang dicari perbedaanya yaitu tidak terlalu besar perbedaan jumlah anggota sampelnya. Adapun satistik uji-t yang digunakan yaitu uji dua pihak karena sesuai dengan tujuan penelitian yang dikemukakan sebelumnya yaitu untuk mengetahui adanya pengaruh pembelajaran self directed learning berbasis teknologi informasi terhadap hasil belajar siswa di kelas X IPA SMA Negeri 9 Palu pada materi struktur atom. Hasil pengujian hipotesis dengan statistik uji-t dua pihak diperoleh nilai $t_{\text {hitung }}>t_{\text {tabel }}$ yaitu $6,5>2,02$ dengan taraf kepercayaan 0,05 dan derajat kebebasan $=49$. Berdasarkan hasil pengujian hipotesis, memberikan gambaran kepada kita bahwa metode pembelajaran self directed learning dapat memberikan pengaruh pada hasil belajar siswa dibandingkan dengan menggunakan metode konvensional. $\mathrm{Hal}$ ini terbukti dengan ditolaknya hipotesis Ho dan diterimanya hipotesis alternatif $\left(\mathrm{H}_{1}\right)$. Penelitian ini menggunakan taraf kepercayaan 0,05 karena diharapkan dalam pengambilan kesimpulan 
kesalahan yang terjadi hanya 5\% saja dan 95\% nya benar.

Suyati (2012) menyatakan terdapat hubungan yang signifikan antara kemandirian belajar dengan prestasi belajar. Kemandirian belajar menyebabkan peserta didik memiliki inisiatif untuk mencari sumber belajarnya sendiri baik itu melalui buku, artikel ilmiah, jaringan internet dan sumber lainnya.

Berdasarkan hasil uji hipotesis, maka $\mathrm{H}_{0}$ ditolak, hal ini menunjukkan bahwametode pembelajaran Self direct learning pada pokok bahasan struktur atom memberikan hasil belajar yang lebih baik dibandingkan dengan pembelajaran menggunakan metode konvensional.

Pembelajaran dalam kelas dibutuhkan semangat kemandirian belajar atau self directed learning. Gibbons (2002) menyatakan bahwa self directed learning adalah peningkatan pengetahuan, keahlian, prestasi, dan mengembangkan diri dimana individu menggunakan banyak metode dalam banyak situasi dalam setiap waktu. SDL meliputi bagaimana siswa belajar setiap harinya, bagaimana siswa dapat menyesuaikan diri dengan keadaan yang cepat berubah, dan bagaimana siswa dapat mengambil inisiatif sendiri ketika suatu kesempatan tidak terjadi atau tidak muncul. Belajar mandiri merupakan kegiatan belajar aktif yang didorong oleh niat atau motivasi untuk menguasai suatu kompetensi guna untuk menyelesaikan suatu masalah, kegiatan ini dibangun dengan bekal pengetahuan atau kompetensi yang telah dimiliki sebelumnya (Mudjiman, 2007).

Model SDL yang dikembangkan oleh Knowles (1975) dan disempurnakan oleh Song \& Hill (2007) terdiri atas tahapan planning, monitoring dan evaluating. Planning merupakan aktivitas awal yang dapat memunculkan indikator berpikir kritis, yaitu mempertimbangkan kredibilitas sumber dan menumbuhkan elemen kemandirian belajar yaitu motivasi, monitoring menciptakan lingkungan belajar dan mengembangkan rencana kegiatan merupakan aktivitas yang dapat memunculkan indikator berpikir kritis yaitu berinteraksi dengan orang lain dan menumbuhkan elemen kemandirian belajar self management dan evaluating berkaitan dengan elemen kemandirian belajar self monitoring. Sintaks model SDL tersebut dapat dihubungkan dengan salah satu faktor yang sangat erat kaitannya dengan SDL yaitu kemandirian belajar.

Pembelajaran yang dapat meningkatkan daya nalar siswa adalah pembelajaran yang membuat siswa aktif dalam berpikir sehingga pembelajaran menjadi terpusat pada siswa, salah satu pembelajaran yang memotivasi siswa untuk aktif dan mandiri dalam belajar adalah pembelajaran mandiri (self directed learning)(Handayani, dkk., 2013). Dengan demikian dapat diajukan beberapa saran sebagai berikut: 1) guru hendaknya mampu mengemas model SDL berbasis lingkungan secara kreatif untuk menarik minat siswa di dalam pembelajaran. 2) pemanfaatan kontrak belajar di dalam model pembelajaran SDL berbasis lingkungan perlu dipertegas untuk meminimalisir penyimpangan siswa terhadap tujuan pembelajaran yang ditetapkan semula (Arjaya, 2013).

\section{Kesimpulan}

Berdasarkan hasil analisis data penelitian, ada pengaruh terhadap hasil belajar kimia siswa yang mendapat perlakuan metode pembelajaran self directed learning dengan pembelajaran menggunakan metode konvensional pada materi struktur atom kelas X di SMA Negeri 9 Palu. Hal ini dapat dilihat dari skor rata-rata post test dari masing-masing kelas, eksperimen $=71,04$ dan kontrol $=64,80$. Hal tersebut diperkuat oleh hasil analisis data statistik dengan nilai $t_{\text {hitung }}>t_{\text {tabel }}$ yaitu 6,5> 2,02 pada taraf signifikan $\alpha=0,05$ dan derajat kebebasan, $\mathrm{dk}=49$ sehingga hipotesis dapat diterima pada taraf kepercayaan $95 \%$.

\section{Ucapan Terima Kasih}

Penulis mengucapkan terimakasih kepada Irsan Kepala SMA Negeri 9 Palu, Alamsyah, Muhlis, dan Armin selaku guru kimia di SMA Negeri 9Palu, seluruh siswa kelas XSMA Negeri 9 Palu, dan seluruh pihak yang telah membantu penulis dalam menyelesaikan penelitian ini.

\section{Daftar Pustaka}

Arjaya, I. B. S. (2013). Model self direct learning berbasis lingkungan dalam pembelajaran biologi. Prosiding Seminar Nasional Biologi, 18.

Bakrowi, A. (2008). Microsoft office powerpoint sebagai media pembelajaran materi, unsur, dan senyawa berbasis STAD. Jurnal Pendidikan Indonesia, 3(1), 1-8.

Bowen, C. W. (1998). Item design consideration for computer based testing of student learning in chemistry. Journal of Chemical Education, 75(9), 1172-1175.

Falestin, Y. (2010). Peningkatan prestasi belajar akuntasi melalui penerapan model pembelajaran problem based learning pada siswa kelas XI IPS 2 SMA Negeri 6 Surakarta tabun ajaran 2009/2010. Skripsi. Surakarta: Universitas Sebelas Maret.

Gibbons, M. (2002). The self-directed learning handbook challenging adolescent student to excel. San Francisco: Jossey-Bass Publishers.

Handayani, N. N. L., Dantes, N. \& Suastra, I. W. (2013). Pengaruh model pembelajaran mandiri terhadap kemandirian belajar dan prestasi belajar IPA siswa kelas VIII SMPN Singaraja. Junal Pendidikan Dasar, 3(1), 1-10.

Knowles, M. S. (1975). Self directed learning a guide for learners and teachers. New York: Association Press.

Liliawati, W., Rustam, N. Y., Herdiwijaya, D. \& Rusdiana, D. (2013). Efektifitas perkuliahan IPBA terintegrasi berbasis kecerdasan majemuk 
untuk meningkatkan penguasaan konsep dan menanamkan karakter diri mahasiswa calon guru SMP pada tema tata surya. Indonesian Jounal of Applied Physics, 13(1), 63-71.

Manggala, I. K. A., Suami, N. K. \& Suarjana, M. (2013). Pengaruh model pembelajaran selfdirected learning terhadap hasil belajar matematika siswa kelas IV SD lab Undiksha Singaraja tahun pembelajaran 2012/2013. Jurnal Universitas Pendidikan Ganesha Singaraja, 1(1), 1-10.

Mudjiman, H. (2007). Belajar mandiri. Yogyakarta: UNY Press.

Rushell, J. W., Kozma, R. B., Jonas, T., Wykoff, J., Marx, N. \& Davis, J. (1997). Use of simultaneous-synchronized macroscopic, microscopic, and symbolic representations to enhance the teaching and learning of chemical concepts. Journal of Chemical Education, 74(3), 330-334.
Setyorini, U. (2011). Penerapan model problem based learning untuk meningkatkan kemampuan berpikir kritis siswa SMP. Jurnal Pendidikan Fisika, 7(1), 52-56.

Song, L. \& Hill, J. R. (2007). A conceptual model for understanding self-directed learning in online environments. Journal of Interactive Online Learning, 6(1), 27-42.

Sudjana. (2005). Metode statistika. Bandung: Tarsito.

Suyati. (2012). Pengaruh kemandirian belajar dengan prestasi belajar mata kuliah keterampilan dasar praktek klinik. Journal Eduhealth, 2(2), 4-6.

Tahar, I. (2006). Hubungan kemandirian belajar dan hasil belajar pada pendidikan jarak jauh. Jurnal Pendidikan Terbuka dan Jarak Jauh, 7(2), 91-101. 